\title{
Automatic volcanic ash detection from MODIS observations using a back-propagation neural network
}

\author{
T. M. Gray and R. Bennartz \\ Department of Earth and Environmental Sciences, Vanderbilt University, Nashville, Tennessee, USA \\ Correspondence to: R. Bennartz (ralf.bennartz@vanderbilt.edu)
}

Received: 12 June 2015 - Published in Atmos. Meas. Tech. Discuss.: 19 August 2015

Revised: 8 November 2015 - Accepted: 11 November 2015 - Published: 8 December 2015

\begin{abstract}
Due to the climate effects and aviation threats of volcanic eruptions, it is important to accurately locate ash in the atmosphere. This study aims to explore the accuracy and reliability of training a neural network to identify cases of ash using observations from the Moderate Resolution Imaging Spectroradiometer (MODIS). Satellite images were obtained for the following eruptions: Kasatochi, Aleutian Islands, 2008; Okmok, Aleutian Islands, 2008; Grímsvötn, northeastern Iceland, 2011; Chaitén, southern Chile, 2008; Puyehue-Cordón Caulle, central Chile, 2011; Sangeang Api, Indonesia, 2014; and Kelut, Indonesia, 2014. The Hybrid Single Particle Lagrangian Integrated Trajectory (HYSPLIT) model was used to obtain ash concentrations for the same archived eruptions. Two back-propagation neural networks were then trained using brightness temperature differences as inputs obtained via the following band combinations: 12 $11,11-8.6,11-7.3$, and $11 \mu \mathrm{m}$. Using the ash concentrations determined via HYSPLIT, flags were created to differentiate between ash (1) and no ash (0) and $\mathrm{SO}_{2}$-rich ash (1) and no $\mathrm{SO}_{2}$-rich ash (0) and used as output. When neural network output was compared to the test data set, $93 \%$ of pixels containing ash were correctly identified and $7 \%$ were missed. Nearly $100 \%$ of pixels containing $\mathrm{SO}_{2}$-rich ash were correctly identified. The optimal thresholds, determined using Heidke skill scores, for ash retrieval and $\mathrm{SO}_{2}$-rich ash retrieval were 0.48 and 0.47 , respectively. The networks show significantly less accuracy in the presence of high water vapor, liquid water, ice, or dust concentrations. Significant errors are also observed at the edge of the MODIS swath.
\end{abstract}

\section{Introduction}

Volcanic eruptions, if large enough, can have a dramatic effect on the climate and the aviation industry, as highly explosive eruptions can emit large amounts of ash and $\mathrm{SO}_{2}$ into the troposphere and stratosphere. Due to climate and aviation impacts, the knowledge of the location of volcanic ash following an eruption is imperative. Although climate effects of eruptions have been mostly attributed to sulfate aerosols, recent research has attempted to quantify climate effects attributable to ash (Langmann, 2014; Flanner et al., 2014). Volcanic ash acts to reduce the amount of incoming solar radiation, thus modifying Earth's surface temperature (Langmann, 2013). Ash, in addition to sulfate aerosols, provides a source of cloud condensation nuclei and ice nuclei, increasing the number of cloud droplets, and thus modifies cloud lifetime and precipitation processes (Langmann, 2013, 2014; Twomey, 1977; Albrecht, 1989). Atmospheric $\mathrm{CO}_{2}$ concentrations can be reduced following volcanic eruptions through ocean fertilization: ash can serve as a source of soluble iron to the ocean, increasing marine primary production (when iron is the limiting nutrient), leading to a buildup of organic carbon (Langmann, 2013, 2014; Achterberg et al., 2013). The presence of ash in the troposphere can also result in surface darkening, snowmelt, and snow insulation (when the ash deposit is thick) (Flanner et al., 2014).

In order to have a significant climate effect, sulfate aerosols must be injected into the stratosphere, because they will be rapidly removed due to precipitation if only injected into the troposphere (Francis and Oppenheimer, 2004). However, a series of smaller eruptions could have a cumulative climate effect due to the amount of sulfate added to the atmosphere (Solomon et al., 2011). Sulfate aerosols, formed after $\mathrm{SO}_{2}$ oxidizes to $\mathrm{H}_{2} \mathrm{SO}_{4}$ by homogeneous nucle- 
ation/condensation onto other aerosols (Vernier et al., 2011), increase Earth's albedo by scattering shortwave radiation. This results in the primary effect of large volcanic eruptions: surface and tropospheric cooling and stratospheric warming (Kravitz and Robock, 2011). Net heating is observed in the stratosphere due to the absorption of infrared radiation by sulfate aerosol. Other effects of sulfate aerosols are ozone depletion and more downward infrared flux (Robock, 2000). However, some researchers suggest that some volcanism, specifically flood basalts, has led to intense global average warming on a longer timescale than $\mathrm{SO}_{2}$ due to the residence time of $\mathrm{CO}_{2}$ (Caldeira and Rampino 1990).

In addition to human health impacts, such as eye irritation and respiratory stress (Langmann, 2013), volcanic ash poses a serious threat to the aviation industry. Ash can melt onto the jet engine turbine and lead to failure if it enters the engine, as the melting point of ash is around $1100 \mathrm{~K}$ while jet engines operate at about $1400 \mathrm{~K}$ (Sears et al., 2013). In addition to engine damage, volcanic ash can also damage cockpit windows and other airplane surfaces through sandblasting, obstruct the pitot-static system, and be ingested into the air conditioning and cooling systems (Pavolonis et al., 2013; International Civil Aviation Organization (ICAO), 2007). Due to these physical damage effects of volcanic ash, the presence of ash in the atmosphere can significantly affect the economy of the aviation industry.

When ash and $\mathrm{SO}_{2}$ follow different trajectories, due to their different densities and the presence of shear, or the change in wind speed and direction with height, and atmospheric lifetime (Carn et al., 2002; Sears et al., 2013; Schneider et al., 1999; Rose et al., 2000; Thomas and Prata, 2011), $\mathrm{SO}_{2}$ cannot reliably be used as a proxy for ash. Sears et al. (2013) found that sometimes only $10 \%$ of ash was missed when using $\mathrm{SO}_{2}$ as a proxy for ash but other times that over $80 \%$ was missed. They go on to discuss that although not always highly accurate, using $\mathrm{SO}_{2}$ to determine the location of volcanic ash is useful.

Previous research determining locations and loadings of $\mathrm{SO}_{2}$ and ash has used one or a combination of the following satellite instruments: Total Ozone Mapping Spectrometer (TOMS), Moderate Resolution Imaging Spectrometer (MODIS), Atmospheric Infrared Sounder (AIRS), Spinning Enhanced Visible and Infrared Imager (SEVIRI), Ozone Monitoring Instrument (OMI), and the Advanced Very High Resolution Radiometer (AVHRR) (Ackerman, 1997; Carn et al., 2009a; Carn and Prata, 2010; Feltz et al., 2006; Prata et al., 2007, 2010; Theys et al., 2013; Pavolonis et al., 2006). Most of these methods are either physical inversions or statistically derived threshold methods. Picchiani et al. (2011) and Piscini et al. (2014) demonstrate the usefulness of neural networks for ash/ $/ \mathrm{SO}_{2}$ detection on a limited set of cases.

Our study aims to further explore the accuracy and reliability of neural networks to detect both ash-rich and $\mathrm{SO}_{2}$-rich volcanic clouds using MODIS, an instrument onboard NASA's Terra and Aqua satellites. In particular, we use a wider range of atmospheric conditions and combine MODIS analysis with the Hybrid Single Particle Lagrangian Integrated Trajectory (HYSPLIT; Draxler and Rolph, 2003) model for neural network training. The remainder of this paper is structured as follows: chosen study areas are outlined in Sect. 2.1, remote sensing methods used to locate volcanic ash and $\mathrm{SO}_{2}$-rich ash in MODIS observations in Sect. 2.2, modeling methods used to determine ash concentrations in Sect. 2.3, and neural network details in Sect. 2.4. Optimal thresholds for detecting ash are discussed in Sect. 3.1. The results of this study, including success rate and accuracy of this detection method, can be found in Sect. 3.2.

\section{Methods}

To determine whether volcanic ash could be automatically detected within MODIS observations, MODIS data were obtained for seven eruptive events (Table 1) and band differencing was performed to distinguish ash and $\mathrm{SO}_{2}$-rich ash from ambient clouds and surface features. Ash locations and concentrations were determined using HYSPLIT for the same eruptive events. The accuracy of using a neural network to detect volcanic ash was explored by training a backpropagation neural network with band differences representing ash, $\mathrm{SO}_{2}$, and surface features as input and ash concentrations as output.

\subsection{Study areas}

Seven eruptive events with similar plume heights and explosivity were chosen (Table 1). These eruptions all had a volcanic explosivity index (VEI) of 3 or 4 and plume heights between 12 and $30 \mathrm{~km}$ (Global Volcanism Program, hereafter referred to as GVP). The VEI is on a scale of 0 to 8 , where an increase of one indicates an increase in magnitude by a factor of 10 and is a function of volume of erupted material, eruption column height, and duration (Newhall and Self, 1982). These eruptive events were chosen because they had similar eruptive column heights, allowing their trajectories to be compared. More information about these specific eruptions can be found in Appendix A. The focus of this paper will be on four of the seven eruptions: Chaitén, Okmok, Kelut, and Sangeang Api. Additional information regarding the other three eruptions has been provided as Supplement. The Supplement also includes detailed information on the MODIS granules used.

\subsection{Remote sensing}

Aerosols exhibit varying transmittance in the 8-10 and 10 $12 \mu \mathrm{m}$ ranges, regions where the atmosphere is nearly transparent (Ackerman, 1997). Because MODIS channels 29, 31, and 32 cover this spectral range, MODIS images were obtained and band combinations were applied to determine areas of ash and $\mathrm{SO}_{2}$ in each eruptive column. Sulfur dioxide 
Table 1. Seven volcanic eruptions and their corresponding time, location, plume height $(\mathrm{km})$, and explosivity.

\begin{tabular}{|c|c|c|c|c|}
\hline Volcano & Date of eruption & Location & $\begin{array}{r}\text { Plume height } \\
(\mathrm{km})\end{array}$ & VEI \\
\hline Kasatochi & 7 Aug 2008 & $52.177^{\circ} \mathrm{N}, 175.508^{\circ} \mathrm{W}$ & $\sim 19$ & 4 \\
\hline Okmok & 12 Jul 2008 & $53.43^{\circ} \mathrm{N}, 168.13^{\circ} \mathrm{W}$ & $\sim 15$ & 4 \\
\hline Grímsvötn & 21 May 2011 & $64.42^{\circ} \mathrm{N}, 17.33^{\circ} \mathrm{W}$ & $\sim 20$ & 4 \\
\hline Chaitén & 6 May 2008 & $42.833^{\circ} \mathrm{S}, 72.646^{\circ} \mathrm{W}$ & $\sim 30$ & 4 \\
\hline Puyehue-Cordón Caulle & 4 Jun 2011 & $40.59^{\circ} \mathrm{S}, 72.117^{\circ} \mathrm{W}$ & $\sim 12$ & 3 \\
\hline Kelut & 13 Apr 2014 & $7.93^{\circ} \mathrm{S}, 112.31^{\circ} \mathrm{E}$ & $\sim 17$ & 4 \\
\hline Sangeang Api & 30 May 2014 & $8.20^{\circ} \mathrm{S}, 119.07^{\circ} \mathrm{E}$ & $\sim 15$ & 3 \\
\hline
\end{tabular}

is very absorptive in 7.3 and $8.6 \mu \mathrm{m}$ channels (Prata et al., 2007). However, the $7.3 \mu \mathrm{m}$ channel is not as sensitive to the total $\mathrm{SO}_{2}$ column as the $8.6 \mu \mathrm{m}$ channel because the $7.3 \mu \mathrm{m}$ channel lies within a band that is also sensitive to water vapor (Sears et al., 2013) (see Fig. 1 in Watson et al., 2004). Band differencing was used to locate both ash and $\mathrm{SO}_{2}$ in the atmosphere following a volcanic eruption. Ash is characterized by a negative brightness temperature difference between 11 and $12 \mu \mathrm{m}$ (Ackerman et al., 2008). Ice is characterized by a positive brightness temperature difference between 11 and $12 \mu \mathrm{m}$ because ice exhibits a lower brightness temperature at $12 \mu \mathrm{m}$ (Watson et al., 2004). Following methods similar to Ackerman et al. (2008), band $31(11 \mu \mathrm{m})$ was subtracted from band $32(12 \mu \mathrm{m})$ to create a positive brightness temperature difference representing ash. Because $\mathrm{SO}_{2}$ absorbs strongly in the $8.6 \mu \mathrm{m}$ channel but not in the $11 \mu \mathrm{m}$ channel, band $29(8.6 \mu \mathrm{m})$ was subtracted from band $31(11 \mu \mathrm{m})$ to create a positive brightness temperature difference representing $\mathrm{SO}_{2}$ (Figs. 1-4). Visible images were also created for each case by combining band $1(620-670 \mathrm{~nm})$, band 4 (545$565 \mathrm{~nm}$ ), and band 3 (459-479 nm) (Figs. 1-4).

\subsection{HYSPLIT}

After band combinations were used to differentiate among ambient clouds, surface features, ash, and $\mathrm{SO}_{2}$, ash concentrations were determined using the HYSPLIT model for volcanic ash for the same archived eruptions (Draxler and Rolph, 2003).

The NOAA/Air Resources Laboratory HYSPLIT model can be used specifically for archived volcanic eruptions to determine the transport, dispersion, and ash concentrations of the volcanic plume. For this particular study, National Centers for Environmental Prediction (NCEP)/National Center for Atmospheric Research (NCAR) Reanalysis meteorological data were used. Reanalysis data are composed of atmospheric analysis reproduced using historical data (1948current) (Kalnay et al., 1996). These concentrations were then used to create "ash" and "no-ash" classifications, which may or may not be representative of reality due to HYSPLIT concentration uncertainties. Parameters specified in this model can be found in Appendix B. Concentrations were

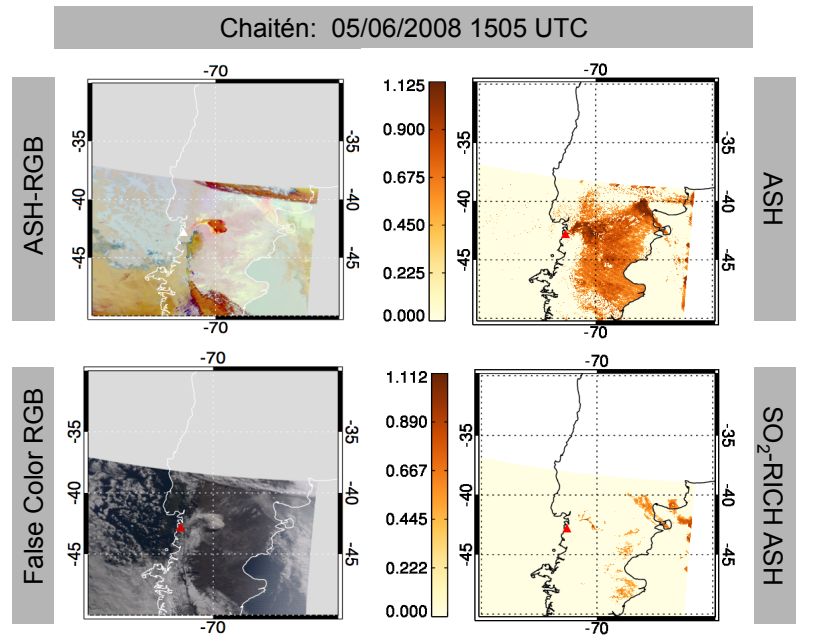

Figure 1. (Top left) Ash-RGB created using MODIS infrared bands 32-31, 31-29, and 31 for the eruption of Chaitén, 6 May 2008, 1505Z; (bottom left) false color RGB image created using MODIS reflective bands 1, 4, and 3 for the same eruption and time; (top right) ash-detection neural network output for the same eruption and time; (bottom right) $\mathrm{SO}_{2}$-rich-ash-detection neural network output for the same eruption and time.

integrated over the concentration layer height of 30 or $32 \mathrm{~km}$, depending on the eruption, resulting in units of $\mathrm{g} \mathrm{m}^{-2}$.

\subsection{Neural network}

A neural network, or a structure that mathematically identifies relationships between given inputs and outputs (Hsu et al., 1995), is made up of neurons, which consist of input signals, a set of weights, activation levels, and threshold functions (Luger and Stubblefield, 1998). Neural networks have varying topologies, learning algorithms, and encoding schemes (Luger and Stubblefield, 1998). This particular study used a back-propagation learning algorithm for a multi-layer neural network, which propagates error backwards starting from the output layer through the hidden layers, which connect the input and output layers (Luger and Stubblefield, 1998). 


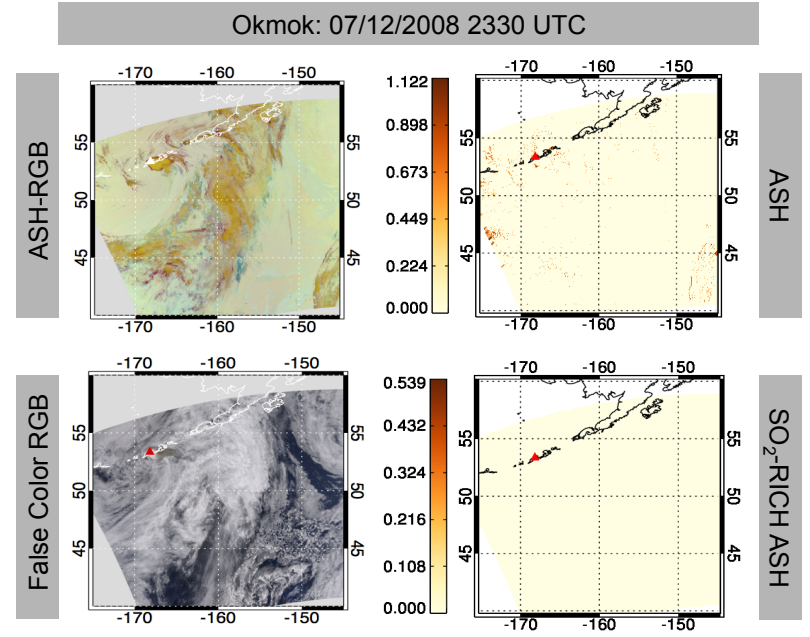

Figure 2. (Top left) Ash-RGB created using MODIS infrared bands 32-31, 31-29, and 31 for the eruption of Okmok, 12 July 2008, 2330Z; (bottom left) false color RGB created using MODIS reflective bands 1, 4, and 3 for the same eruption and time; (top right) ash-detection neural network output for the same eruption and time; (bottom right) $\mathrm{SO}_{2}$-rich-ash-detection neural network output for the same eruption and time.

\subsubsection{Neural network training}

Two back-propagation neural networks were used to determine whether or not ash or $\mathrm{SO}_{2}$-rich ash was present in a given MODIS pixel. From 120 MODIS granules, 14 cases were chosen where HYSPLIT output was well aligned with satellite observations (Appendix B). Three masks were applied to each granule to create a selection of pixels containing only ash, a selection containing only $\mathrm{SO}_{2}$-rich ash, and a selection containing all other situations where ash was not present. Both networks were trained using inputs obtained via the following band combinations: $12-11 \mu \mathrm{m}$ brightness temperature difference, $11-8.6 \mu \mathrm{m}$ brightness temperature difference, $11-7.3 \mu \mathrm{m}$ brightness temperature difference, and $11 \mu \mathrm{m}$ brightness temperature. Using the ash concentrations determined via HYSPLIT, two sets of flags were created to differentiate between ash (1) and no ash (0) and $\mathrm{SO}_{2}$-rich ash (1) and no $\mathrm{SO}_{2}$-rich ash (0). As validation, the neural networks used these flag as outputs. The back-propagation neural network settings used in this study can be found in the Supplement. René Preusker of the Institute for Space Sciences, Free University of Berlin, Germany, created the software used in this study for the training of this particular neural network.
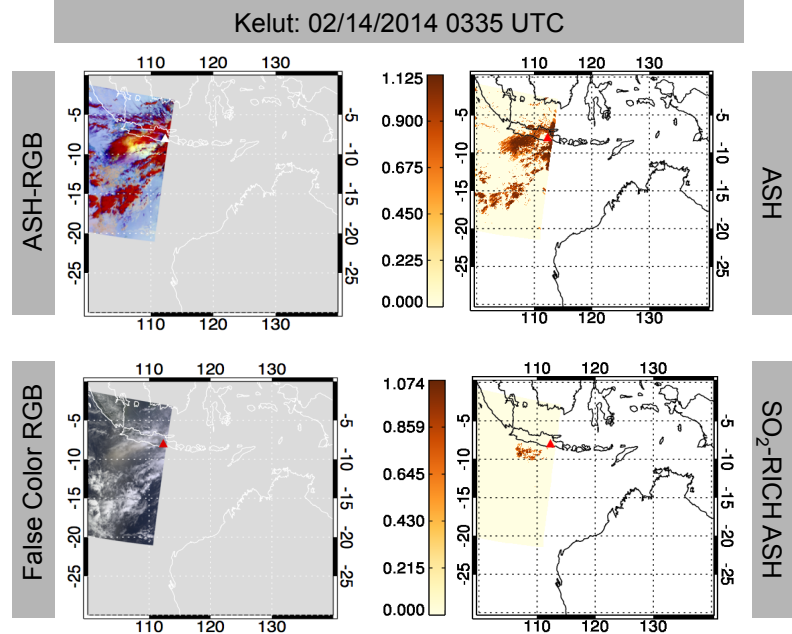

Figure 3. (Top left) Ash-RGB created using MODIS infrared bands 32-31, 31-29, and 31 for the eruption of Kelut, 14 February, 0335Z; (bottom left) false color RGB created using MODIS reflective bands 1,4 , and 3 for the same eruption and time; (top right) ash-detection neural network output for the same eruption and time; (bottom right) $\mathrm{SO}_{2}$-rich-ash-detection neural network output for the same eruption and time.

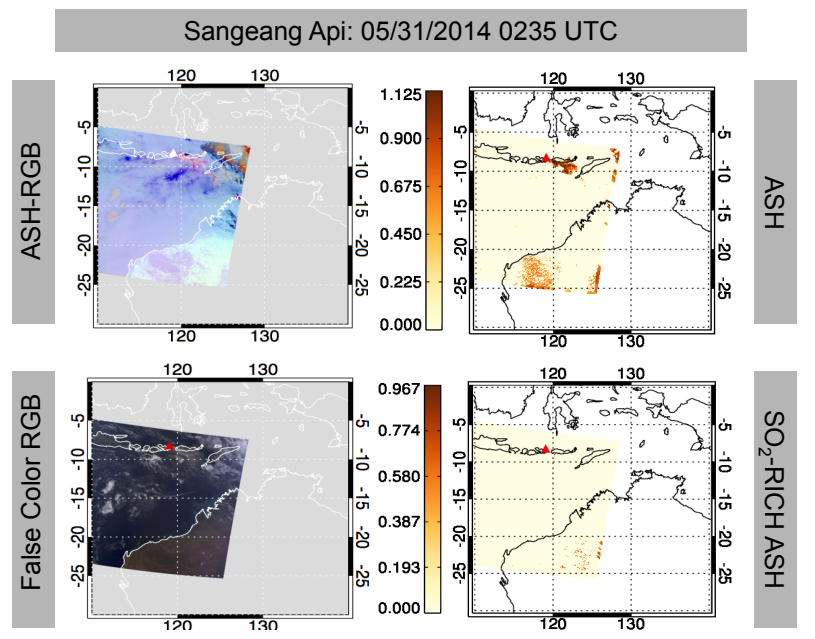

Figure 4. (Top left) Ash-RGB created using MODIS infrared bands 32-31, 31-29, and 31 for the eruption of Sangeang Api, 31 May 2014, 0235Z; (bottom left) false color RGB image created using MODIS reflective bands 1, 4, and 3 for the same eruption and time; (top right) ash-detection neural network output for the same eruption and time; (bottom right) $\mathrm{SO}_{2}$-rich-ash-detection neural network output for the same eruption and time.

\section{Results}

\subsection{Optimal thresholds}

The neural network output was compared to the test data set output for both the ash-detection and $\mathrm{SO}_{2}$-rich-ash-detection networks. A Heidke skill score was calculated for all possible 
ash/no ash and $\mathrm{SO}_{2}$-rich ash/no $\mathrm{SO}_{2}$-rich ash thresholds to determine optimal thresholds (Figs. 5 and 6). Data used to make these plots have been provided.

The optimal thresholds for ash retrieval and $\mathrm{SO}_{2}$-rich ash retrieval were 0.48 and 0.47 , respectively. The $\mathrm{SO}_{2}$-rich-ashdetection neural network was found to have a higher Heidke skill score than the ash-detection neural network and thus less error (Table 2). Of all data containing volcanic ash, $93 \%$ of pixels are correctly identified and $7 \%$ are incorrectly flagged (Table 2). Out of the all data containing $\mathrm{SO}_{2}$-rich ash, almost $100 \%$ are correctly identified (Table 2 ).

\subsection{Neural network output}

Using the optimal thresholds determined by the Heidke skill score test, MODIS granules for the specified eruptions were fed to the neural network to create new images locating areas of ash, no ash, $\mathrm{SO}_{2}$-rich ash, and no $\mathrm{SO}_{2}$-rich ash (Figs. 14). The scales associated with the neural network output in Figs. 1-4 are representative of certainty of the presence of ash or $\mathrm{SO}_{2}$-rich ash in that pixel, where a greater number represents a greater likelihood that ash is present.

Referring back to the corresponding RGBs in Figs. 1-4, the neural network output in those figures differentiates the pink/red areas, representing ash in the RGBs, from the ambient environment and $\mathrm{SO}_{2}$, and also differentiates the bright yellow, representing $\mathrm{SO}_{2}$-rich ash in the $\mathrm{RGBs}$, from the ambient environment and ash. In addition, when ash and $\mathrm{SO}_{2}$ are collocated or when $\mathrm{SO}_{2}$ is located above ash, ash will appear bright yellow in RGBs created using the band combinations. This is due to the strong $\mathrm{SO}_{2}$ absorption in $8.6 \mu \mathrm{m}$ combined with the lack of absorption in 11 and $12 \mu \mathrm{m}$. Chaitén, one of two midlatitude eruptions analyzed in this study, is represented in Fig. 1. Four days before this particular image was captured by MODIS, Chaitén erupted with a $21 \mathrm{~km}$ plume that drifted to the southeast, east, west, and northeast (GVP). A second eruption occurred on 6 May 2008, 12:32 UTC, about $2.5 \mathrm{~h}$ prior to this image. At first glance, it would appear that the neural network is greatly overestimating ash east of the volcano. However, there are no high meteorological clouds in this region, as seen in visible image in Fig. 1, and previous eruptions from days earlier contributed a significant portion of ash to the atmosphere. It is likely that the neural network is detecting low-level ash from previous eruptions to the east of the volcano (Fig. 1). A strong signal is also observed to the east-northeast of the volcano, likely from the previous Plinian column erupting from this volcano on 2 May 2008 (Fig. 1). The neural network detected little $\mathrm{SO}_{2}$ (Fig. 1), as this particular eruption was not characterized by high $\mathrm{SO}_{2}$ emissions (Lara, 2009; Carn et al., 2009b).

The eruption of Okmok, Aleutian Islands, is unique because it was phreatomagmatic, or characterized by high water content (GVP). This eruption incorporated ground water and water inside the caldera (GVP). The RGB in Fig. 2 does not contain the bright red/pink signature usually observed for
Table 2. (Top) Ash-detection neural network output was compared to the test data set output to measure success; (bottom) $\mathrm{SO}_{2}$-richash-detection neural network output was compared to the test data set to measure success.

\begin{tabular}{|c|c|c|}
\hline \multirow[t]{2}{*}{ Ash observed } & \multicolumn{2}{|c|}{ Ash predicted } \\
\hline & No & Yes \\
\hline No & $87.7 \%$ & $12.3 \%$ \\
\hline Yes & $6.8 \%$ & $93.2 \%$ \\
\hline \multirow{2}{*}{$\begin{array}{l}\mathrm{SO}_{2} \text {-rich ash } \\
\text { observed }\end{array}$} & \multicolumn{2}{|c|}{$\mathrm{SO}_{2}$-rich ash predicted } \\
\hline & No & Yes \\
\hline No & $98.4 \%$ & $1.6 \%$ \\
\hline Yes & $0.03 \%$ & $99.97 \%$ \\
\hline
\end{tabular}

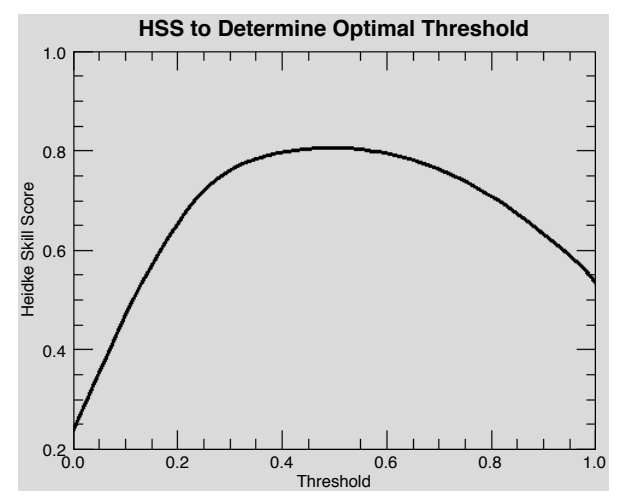

Figure 5. Optimal threshold for ash retrieval determined is 0.48 with Heidke skill score of 0.81 .

ash, although a $15 \mathrm{~km}$ plume is reported (GVP) and an ash signature is clear in the visible image. When high amounts of water are incorporated into ash clouds, they lose their ash signature and begin to appear more like meteorological clouds than ash clouds (Prata, 2009), which explains why the neural network is not discerning the volcanic cloud in this particular case. There is also no $\mathrm{SO}_{2}$-rich ash detected because a $\mathrm{SO}_{2}$ signature is not present with this eruption at this time.

Neural network output for the eruption of Kelut is shown in Fig. 3. This particular image was captured by MODIS about $3 \mathrm{~h}$ after the initial eruption. The $17 \mathrm{~km}$ plume was observed drifting northeast, northwest, and west (GVP). Upon analysis of the RGB (Fig. 3), it is difficult to differentiate the ash cloud from surrounding meteorological clouds. As this volcano is located in the tropics, characterized by high atmospheric water vapor concentrations, this is not surprising. Kristiansen et al. (2015) found this volcanic cloud difficult to detect within the first several hours of eruption due to the thickness of the ash cloud combined with the high amounts of ice coating within surrounding meteorological clouds. However, the $\mathrm{SO}_{2}$ signal is easily distinguishable from the ambient environment in both the RGB (Fig. 3) and the neural network output (Fig. 3). 


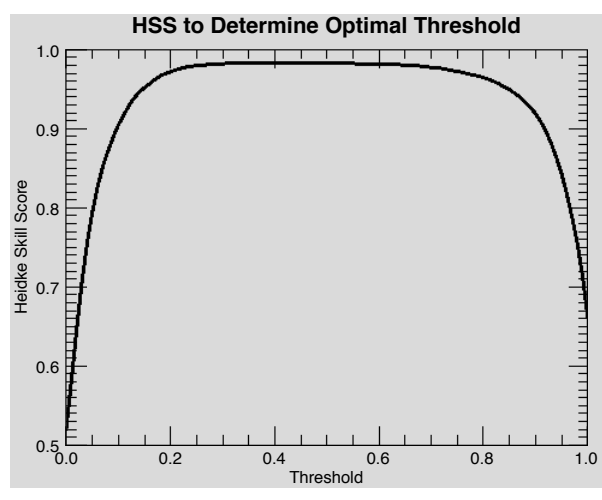

Figure 6. Optimal threshold for $\mathrm{SO}_{2}$-rich ash retrieval determined is 0.47 with Heidke skill score of 0.98 .

The volcanic cloud that erupted from Sangeang Api about $18 \mathrm{~h}$ after the initial eruption is depicted in Fig. 4. The initial plume was observed drifting west at $3 \mathrm{~km}$ altitude and eastsoutheast at $15.2 \mathrm{~km}$ altitude (GVP). A bright pink ash signal is observed to the east-southeast in the RGB, and the same signal is observed as brown in the visible image (Fig. 4), corroborating weekly reports (GVP). However, a pink signal is also observed over western Australia. This is most likely dust from the deserts of Australia, as dust has similar radiative properties to volcanic ash. No $\mathrm{SO}_{2}$ signal is observed in the RGB (Fig. 4). The neural network distinguishes ash from the ambient environment but overestimates in the presence of dust (Fig. 4). The neural network correctly places no $\mathrm{SO}_{2}$ signal in this particular observation (Fig. 4).

\section{Discussion}

In this study a neural-network-based algorithm was developed to detect volcanic ash and $\mathrm{SO}_{2}$-rich ash using MODIS observations. Based on the test and training data, the neural was able to detect ash and $\mathrm{SO}_{2}$ with a high accuracy. In particular, the combination of $\mathrm{SO}_{2}$ and ash was easily detected by the neural network. However, the neural network shows significantly less accuracy when the volcanic cloud is characterized by high water or ice content or when surrounded by water or ice-rich meteorological clouds. As water, ice, and water vapor can act to mask the ash signal, the accuracy of ash retrievals is highly dependent on the amount for water vapor in the atmosphere (Watson et al., 2004). Because of this, the neural network is likely to have a higher accuracy in dry atmospheres. High, ice-rich meteorological clouds that are observed to lead to significant ash overestimation are present in Fig. 3. In addition to water vapor adjusting the amounts of ash detected, $\mathrm{SO}_{2}$ can also mask a volcanic ash signal, as mentioned in the previous section. In the event that $\mathrm{SO}_{2}$ and ash are collocated, or when $\mathrm{SO}_{2}$ is located above ash, it is helpful to use visible images (MODIS bands $1,4,3$ ) to determine whether an ash signal is present in the visible image in the same location as the $\mathrm{SO}_{2}$ signal in the RGB. This method, however, cannot be used at night. Ash is also overestimated in the presence of high dust concentrations, as seen in Fig. 4, as dust over western Australia is incorrectly classified as ash. Overestimations that have not yet been mentioned are located on the edges of the MODIS swath, which occur likely due to unfavorable satellite observation angles. This overestimation has not been corrected in this particular network, but will be addressed in future work. In particular, we plan to extend our validation/training database. This would allow us to train a revised network explicitly accounting for zenith angle variations.

In order to train the network, HYSPLIT was treated to be representative of reality. This may not always be accurate, especially for eruptions characterized by multiple eruptive pulses. One of the limitations of HYSPLIT is that it can only be used with one eruptive pulse or one continuous ash release. Chaitén, which was characterized by two significant eruptive pulses 4 days apart, was one case where HYSPLIT and MODIS were not well aligned. The second pulse was analyzed in this study, but low-level ash was still present in the atmosphere from the previous eruption. HYSPLIT had no way to account for this, which could lead to missed ash within the training of the neural network. Another limitation of this study is the lack of knowledge about erupted ash quantity from some events. When unknown, USGS parameters were used, which could lead to significant errors within HYSPLIT and thus the training of the neural network.

The location of volcanic ash in the atmosphere is crucial information for the aviation industry, as volcanic ash can heavily damage jet engines and other parts of aircraft, as discussed in Sect. 2.6. The particular study presented here provides a first step toward an automatic application, which eventually might provide for a fast and effective application to provide information on volcanic ash in an operational context. However, this study does not yet provide information about the concentration of ash in each pixel or the altitude of the ash. Currently, this study only provides confirmation of the presence of ash and/or $\mathrm{SO}_{2}$-rich ash within a $30 \mathrm{~km}$ vertical column.

Future work will include determining the accuracy of training an additional neural network to detect not only whether or not ash is present but also ash concentration and ash cloud altitude. 


\section{Appendix A: Volcanoes}

Located in the Aleutian Islands, the basaltic shield volcano Okmok, erupted at 19:43 UTC on 12 July 2008 (Fee et al., 2010), with a plume height near $15 \mathrm{~km}$ (GVP). This phreatomagmatic eruption, or one characterized by high water content (Fee et al., 2010), released $0.1 \mathrm{Tg}$ of $\mathrm{SO}_{2}$ (Prata et al., 2010).

Chaitén, a rhyolitic caldera in southern Chile, began erupting on 2 May 2008 (Lara, 2009). This eruptive event continued for months, but on 6 May 2008, 12:32 UTC, produced the second Plinian column of the event with a plume height of over $20 \mathrm{~km}$ (Lara, 2009; GVP). This eruption is especially interesting as it was the first rhyolitic eruption during the satellite era (Lara, 2009). This eruption was not associated with high $\mathrm{SO}_{2}$ emissions (Lara, 2009; Carn et al., 2009b).

On 13 February 2014, 15:50 UTC, Kelut, a stratovolcano located in Java, began erupting. This eruption sent volcanic ash to altitudes of $17 \mathrm{~km}$, continued for 3-4 days, and resulted in 40 canceled flights and multiple rerouted flights (GVP; Kristiansen et al., 2015). Kelut is estimated to have injected a total of $0.74 \mathrm{Tg}$ of ash into the atmosphere, and $0.38 \mathrm{Tg}$ of that ash into the stratosphere (Kristiansen et al., 2015).

Sangeang Api, a volcanic complex in the Lesser Sunda Islands (Sigurdsson, 2000), began erupting on 30 May 2014, 08:55 UTC (GVP). This trachybasaltic-to-trachyandesitic complex emitted ash up to $15.2 \mathrm{~km}$ and resulted in canceled flights from the Darwin International Airport (GVP). 


\section{The Supplement related to this article is available online at doi:10.5194/amt-8-5089-2015-supplement.}

Acknowledgements. The authors would like to thank M. Pavolonis of NOAA as well as the two anonymous reviewers for helpful scientific discussions. A special thanks also goes to J. Rausch at Vanderbilt University for programming assistance. This work was supported by an internal Vanderbilt research grant awarded to Ralf Bennartz.

Edited by: A. Kokhanovsky

\section{References}

Achterberg, E. P., Moore, C. M., Henson, S. A., Steigenberger, S., Stohl, A., Eckhardt, S., Avendano, L. C., Cassidy, M., Hembury, D., Klar, J. K., Lucas, M. I., Macey, A. I., Marsay, C. M., and Ryan-Keogh, T. J.: Natural iron fertilization by the Eyjafjallajökull volcanic eruption, Geophys. Res. Lett., 40, 921-926, 2013.

Ackerman, S. A.: Remote sensing aerosols using satellite infrared observations, J. Geophys. Res.-Atmos., 102, 1706917079, 1997.

Ackerman, S. A., Schreiner, A. J., Schmit, T. J., Woolf, H. M., Li, J., and Pavolonis, M.: Using the GOES Sounder to monitor upper level $\mathrm{SO}_{2}$ from volcanic eruptions, J. Geophys. Res., 113, D14s11, doi:10.1029/2007jd009622, 2008.

Albrecht, B. A.: Aerosols, cloud microphysics, and fractional cloudiness, Science, 245, 1227-1230, 1989.

Caldeira, K. G. and Rampino, M. R.: Deccan volcanism, greenhouse warming, and the Cretaceous/Tertiary boundary, Geol. S. Am. S., 247, 117-124, 1990.

Carn, S. A. and Prata, F. J.: Satellite-based constraints on explosive $\mathrm{SO}_{2}$ release from Soufrière Hills Volcano, Montserrat, Geophys. Res. Lett., 37, L00E22, doi:10.1029/2010GL044971, 2010.

Carn, S. A., Schneider, D. J., Bluth, G. J., Kobs, S. E., Rose, W. I., and Ernst, G. G.: On the separation of ash and sulfur dioxide in volcanic clouds, AGU Spring Meeting Abstracts, Abstract V51A-03, Washington, DC, 28-31 May, 2002.

Carn, S. A., Krueger, A. J., Krotkov, N. A., Yang, K., and Evans, K.: Tracking volcanic sulfur dioxide clouds for aviation hazard mitigation, Nat. Hazards, 51, 325-343, 2009a.

Carn, S. A., Pallister, J. S., Lara, L., Ewert, J. W., Watt, S., Prata, A. J., Thomas, R. J., and Villarosa, G.: The Unexpected Awakening of Chaitén Volcano, Chile, EOS T. Am. Geophys. Un., 90, 205-206, 2009b.

Draxler, R. R. and Rolph, G. D.: HYSPLIT (Hybrid Single-Particle Lagrangian Integrated Trajectory) Model access via NOAA ARL READY Website, available at: http://www.arl.noaa.gov/ready/ hysplit4.html (last access: 15 August 2015), NOAA Air Resources Laboratory, Silver Spring, MD, USA, 2003.

Fee, D., Steffke, A., and Garces, M.: Characterization of the 2008 Kasatochi and Okmok eruptions using remote infrasound arrays, J. Geophys. Res., 115, D00L10, doi:10.1029/2009JD013621, 2010 .
Feltz, W. F., Bedka, K., Wimmers, A. J., Pavolonis, M., Bedka, S. M., and Ackerman, S.: Satellite-derived products to enhance aviation nowcasting of convection, turbulence, and volcanic ash, Paper presented at the 14th Conference on Satellite Meteorology and Oceanography, 27 January-3 February 2006, Atlanta, GA, 2006.

Flanner, M. G., Gardner, A. S., Eckhardt, S., Stohl, A., and Perket, J.: Aerosol radiative forcing from the 2010 Eyjafjallajökull volcanic eruptions, J. Geophys. Res.-Atmos., 119, 9481-9491, 2014.

Francis, P. and Oppenheimer, C.: Volcanoes, Oxford UP, Oxford, 536 pp., 2004.

Global Volcanism Program (GVP): http://www.volcano.si.edu/, last access: 15 April 2014.

Hsu, K. L., Gupta, H. V., and Sorooshian, S.: Artificial neuralnetwork modeling of the rainfall-runoff process, Water. Resour. Res., 31, 2517-2530, 1995.

ICAO (International Civil Aviation Organization): Manual on Volcanic Ash, Radioactive Material, and Toxic Chemical Clouds, 2nd edn., Doc 9691-AN/954, International Civil Aviation Organization, 999 University Street, Montréal, Quebec, Canada H3C 5H7, 2007.

Kalnay, E., Kanamitsu, M., Kistler, R., Collins, W., Deaven, D., Gandin, L., Iredell, M., Saha, S., White, G., Woollen, J., Zhu, Y., Chelliah, M., Ebisuzaki, W., Higgins, W., Janowiak, J., Mo, K. C., Ropelewski, C., Wang, J., Leetmaa, A., Reynolds, R., Jenne, R., and Joseph, D.: The NCEP/NCAR 40-year reanalysis project, B. Am. Meteorol. Soc., 77, 437-471, 1996.

Klüser, L., Erbertseder, T., and Meyer-Arnek, J.: Observation of volcanic ash from Puyehue-Cordón Caulle with IASI, Atmos. Meas. Tech., 6, 35-46, doi:10.5194/amt-6-35-2013, 2013.

Kravitz, B. and Robock, A.: Climate effects of high-latitude volcanic eruptions: role of the time of year, J. Geophys. Res., 116 , D01105, doi:10.1029/2010JD014448, 2011

Kristiansen, N. I., Prata, A. J., Stohl, A., and Carn, S. A.: Stratospheric volcanic ash emissions from the 13 February 2014 Kelut eruption, Geophys. Res. Lett., 42, 588-596, 2015.

Langmann, B.: Volcanic ash versus mineral dust: atmospheric processing and environmental and climate impacts, ISRN Atmospheric Sciences, 2013, 1-17, 2013.

Langmann, B.: On the role of climate forcing by volcanic sulphate and volcanic ash, Advances in Meteorology, 2014, 1-17, 2014

Lara, L. E.: The 2008 eruption of the Chaitén Volcano, Chile: a preliminary report, Andean Geol., 36, 125-129, 2009.

Luger, G. and Stubblefield, W.: Artificial intelligence: Structures and Strategies for Complex Problem Solving, 3, Addison Wesley Longman, Reading, MA, 740 pp., 1998.

Newhall, C. G. and Self, S.: The volcanic explosivity index (VEI) an estimate of explosive magnitude for historical volcanism, J. Geophys. Res., 87, 1231-1238, doi:10.1029/JC087iC02p01231, 1982.

Pavolonis, M. J., Feltz, W. F., Heidinger, A. K., and Gallina, G. M.: A daytime complement to the reverse absorption technique for improved automated detection of volcanic ash, J. Atmos. Ocean. Tech., 23, 1422-1444, 2006.

Pavolonis, M. J., Heidinger, A. K., and Sieglaff, J.: Automated retrievals of volcanic ash and dust cloud properties from upwelling infrared measurements, J. Geophys. Res., 118, 14361458, doi:10.1002/jgrd.50173, 2013 
Picchiani, M., Chini, M., Corradini, S., Merucci, L., Sellitto, P., Del Frate, F., and Stramondo, S.: Volcanic ash detection and retrievals using MODIS data by means of neural networks, Atmos. Meas. Tech., 4, 2619-2631, doi:10.5194/amt-4-2619-2011, 2011.

Piscini, A., Picchiani, M., Chini, M., Corradini, S., Merucci, L., Del Frate, F., and Stramondo, S.: A neural network approach for the simultaneous retrieval of volcanic ash parameters and $\mathrm{SO}_{2}$ using MODIS data, Atmos. Meas. Tech., 7, 4023-4047, doi:10.5194/amt-7-4023-2014, 2014.

Prata, A. J.: Satellite detection of hazardous volcanic clouds and the risk to global air traffic, Nat. Hazards, 51, 303-324, 2009.

Prata, A. J., Carn, S. A., Stohl, A., and Kerkmann, J.: Long range transport and fate of a stratospheric volcanic cloud from Soufrière Hills volcano, Montserrat, Atmos. Chem. Phys., 7, 5093-5103, doi:10.5194/acp-7-5093-2007, 2007.

Prata, A. J., Gangale, G., Clarisse, L., and Karagulian, F.: Ash and sulfur dioxide in the 2008 eruptions of Okmok and Kasatochi: insights from high spectral resolution satellite measurements, J. Geophys. Res., 115, D00L18, doi:10.1029/2009JD013556, 2010.

Robock, A.: Volcanic eruptions and climate, Rev. Geophys., 38, 191-219, 2000.

Rose, W. I., Bluth, G. J. S., and Ernst, G. G. J.: Integrating retrievals of volcanic cloud characteristics from satellite remote sensors: a summary, Philos. T. R. Soc A, 358, 1585-1606, 2000.

Schneider, D. J., Rose, W. I., Coke, L. R., Bluth, G. J., Sprod, I. E., and Krueger, A. J.: Early evolution of a stratospheric volcanic eruption cloud as observed with TOMS and AVHRR, J. Geophys. Res.-Atmos., 104, 4037-4050, 1999.

Sears, T. M., Thomas, G. E., Carboni, E., A. Smith, A. J., and Grainger, R. G.: $\mathrm{SO}_{2}$ as a possible proxy for volcanic ash in aviation hazard avoidance, J. Geophys. Res.-Atmos., 118, 5698$5709,2013$.
Sigurdsson, H.: Encyclopedia of Volcanoes, Academic Press, San Diego, CA, 1417 pp., 2000.

Solomon, S., Daniel, J. S., Neely III, R. R., Vernier, J.-P., Dutton, E. G., and Thomason, L. W.: The persistently variable "background" stratospheric aerosol layer and global climate change, Science, 333, 866-870, 2011.

Theys, N., Campion, R., Clarisse, L., Brenot, H., van Gent, J., Dils, B., Corradini, S., Merucci, L., Coheur, P.-F., Van Roozendael, M., Hurtmans, D., Clerbaux, C., Tait, S., and Ferrucci, F.: Volcanic $\mathrm{SO}_{2}$ fluxes derived from satellite data: a survey using $\mathrm{OMI}$, GOME-2, IASI and MODIS, Atmos. Chem. Phys., 13, 59455968, doi:10.5194/acp-13-5945-2013, 2013.

Thomas, H. E. and Prata, A. J.: Sulphur dioxide as a volcanic ash proxy during the April-May 2010 eruption of Eyjafjallajökull Volcano, Iceland, Atmos. Chem. Phys., 11, 6871-6880, doi:10.5194/acp-11-6871-2011, 2011.

Twomey, S.: Influence of pollution on shortwave albedo of clouds, J. Atmos. Sci., 34, 1149-1152, 1977.

Vernier, J. P., Thomason, L. W., Pommereau, J. P., Bourassa, A., Pelon, J., Garnier, A., Hauchecorne, A., Blanot, L., Trepte, C., Degenstein, D., and Vargas, F.: Major influence of tropical volcanic eruptions on the stratospheric aerosol layer during the last decade, Geophys. Res. Lett., 38, L12807, doi:10.1029/2011GL047563, 2011.

Watson, I. M., Realmuto, V. J., Rose, W. I., Prata, A. J., Bluth, G. J. S., Gu, Y., Bader, C. E., and Yu, T.: Thermal infrared remote sensing of volcanic emissions using the moderate resolution imaging spectroradiometer, J. Volcanol. Geoth. Res., $135,75-89,2004$ 